\title{
The potential of recycling and reusing municipal solid waste incinerator ash in Taiwan
}

\author{
Chin-Ming Huang ${ }^{\mathrm{a}, *}$, Wan-Fa Yang ${ }^{\mathrm{a}}$, Hwong-Wen Ma ${ }^{\mathrm{a}}$, Yii-Ren Song ${ }^{\mathrm{b}}$ \\ a National Taiwan University, Graduate Institute of Environmental Engineering, 71, Chou-Shan Road, Taipei, 106, Taiwan, Republic of China \\ ${ }^{\mathrm{b}}$ Environmental Protection Administration, Department of Waste Management, 41, Jhong-Hua Road, Sec. 1, Taipei, 100, Taiwan, Republic of China
}

Accepted 15 September 2005

Available online 16 November 2005

\begin{abstract}
By 2004, there were 19 municipal solid waste incinerators (MSWI) with a total yearly treatment capacity of 7.72 million tons in service in Taiwan. All 19 incinerators operated daily to generate about 1.05 million tons of incinerator ash, including bottom ash and stabilized fly ash in 2003, and the average ash yield is $18.67 \%$. The total number of incinerators is expected to increase to 27 , serving almost all cities in Taiwan by 2007. The authors have suggested a set of criteria based on the yield of incinerator ash $(\Phi)$ to study the ash recycle and reuse potential. The Taiwan Environmental Protection Administration has studied the treatment and reuse of MSWI ashes for many years and collected references on international experience accumulated by developed nations for establishing policies on treatment and reuse of MSWI ashes. These citations were analyzed as the basis for current governmental decision making on policies and factors to be considered for establishing policies on recycle and reuse of MSWI ashes. Feasible applications include utilization of ashes, which after sieving and separation of metal particles, produce granular materials. When granular materials comply with TCLP limitations, they can be utilized as cement additives or road base. The procedures of evaluation have been proposed in the performance criteria to be included in the proposed decision-making process of ash utilization.
\end{abstract}

(C) 2005 Elsevier Ltd. All rights reserved.

\section{Introduction}

In Taiwan, the economic boom has caused an explosive increase in the amounts of municipal solid waste (MSW) generated. During the past decade, much effort has been undertaken in Taiwan to reduce the quantity of MSW and improve its management. A number of laws and regulations on measures and guidelines based on scientific and technical aspects have been issued in order to implement a rational and integrated waste management system nationwide for managing about 300 MSW sanitary landfill sites. The selection procedure for landfill sites is difficult, and MSW handling and disposal is costly. Because of limited space available on the island for establishing new MSW disposal sites, incineration is emphasized as the predominant pretreatment method for MSW. Since 1990, the Taiwan

\footnotetext{
${ }^{*}$ Corresponding author. Tel.: +8862 23621165; fax: +886223626373. E-mail address: d90541011@ntu.edu.tw (C.-M. Huang).
}

Environmental Protection Administration (TEPA) created a series of municipal solid waste incinerator (MSWI) construction projects (namely public infrastructure projects) to build one incinerator for each city or county to resolve the tremendous waste problems in Taiwan. Due to a deficit budget for official business, TEPA introduced the private sector into other MSWI construction and operation projects (namely Build-Operation-Transfer or Build-Operation-Own projects) during its evolution as a waste disposal technological industry. The purpose of this paper is to provide an overview of the MSW ash management situation in Taiwan with emphasis on the present status and decision-making for utilization of the potential of MSWI bottom ash.

\section{Overview of MSW generation and characterization}

Since 1987, Taiwan's government planned for immense improvements in infrastructure in waste-to-energy facilities 
to manage Taiwan's MSW. There are 19 municipal solid waste incinerators (MSWI) with a total design capacity for treatment of 7.72 million tons of waste per year (21,150 tons per day) currently in service all over Taiwan. By 2007, an additional eight MSWIs will be built to serve all cities in the country. Most MSWIs are equipped with more than one line using different types of grates, e.g., roller or reciprocating system. The capacity per line is between 300 and 450 tons per day for waste-to-energy recovery, and the total capacity of Taiwan incinerators ranges from 300 to 1800 tons per day. In 2003, approximately 5.47 million tons, which is $70 \%$ by weight of MSW generated, were incinerated.

MSWI residues are mainly bottom ashes that remain after combustion and fly ashes that are removed from exhaust flue gases. The former consists of grate ash, grate siftings and heat recovery ash; the latter comprises fly ash and residues from the air pollution controlled device. After combustion of MSW, the MSWIs generate about 1.05 million tons of incinerator ash per year including $90 \%$ bottom ash and $10 \%$ fly ash by weight from air pollution control devices. Table 1 shows the MSWI operational data excerpted from the TEPA statistic report for calendar year 2003 (TEPA, 2004a). Waste composition is reflective of wealth and the level of industrialization. The available capacity factor (daily treated quantity/design capacity/ 0.85 ) of all MSWI is $85.51 \%$ with several incinerators exceeding $100 \%$, but remains below the acceptable level of $110 \%$ as under the operation and maintenance experimental conditions. The factor of four plants is below
$70 \%$, owing to maintenance and yearly repair schedules, and troubleshooting for shut-downs or accidents.

\section{Present status of MSWI ash management}

At some MSWIs, which were constructed during the early stage of the MSWI implementation project, the bottom ash and fly ash were collected as a mixture and disposed of as a combined ash. Since results of recent ash characterization research have indicated that heavy metals, e.g., lead and cadmium may have the potential to leach out from fly ash in the field (TEPA, 2004b), TEPA has modified the design criteria for constructing MSWIs with different systems so that bottom ash and fly ash are collected separately. Both the bottom ash and fly ash are subjected to the toxicity characteristic leaching procedure (TCLP) (TEPA, 2002a). If the heavy metal leaching concentrations of the ash comply with the limit value of TCLP, the ash is disposed of as a non-hazardous waste (TEPA, 2002b). Data from local government shows MSWI ash as composed of bottom ash and stabilized fly ash including reacted fly ash. The comparison of heavy metals in MSWI ash is reviewed and outlined in Table 2. According to the newly amended "Waste Disposal Act" (TEPA, 2002c), fly ash is considered as and disposed of as a hazardous waste.

According to the "Measures for Recycling, Cleanup and Disposal of General Wastes (amendment)" (TEPA, 2002d), there are three categories of disposal sites to be constructed in Taiwan. They are: (1) landfill for inert waste, (2) sanitary

Table 1

Operation profile of the MSWIs in Taiwan (2003)

\begin{tabular}{|c|c|c|c|c|c|c|c|}
\hline No. & Location & $\begin{array}{l}\text { Design } \\
\text { capacity } \\
\text { (tons/day) }\end{array}$ & $\begin{array}{l}\text { MSW } \\
\text { incinerated } \\
\text { (tons/day) }\end{array}$ & $\begin{array}{l}\text { Available } \\
\text { capacity } \\
\text { factor }(\%)\end{array}$ & $\begin{array}{l}\text { Incinerator ash } \\
\text { (tons/day) }\end{array}$ & $\begin{array}{l}\text { Yield of } \\
\text { incinerator } \\
\text { ash, } \Phi(\%)\end{array}$ & Completion \\
\hline 1 & Taipei City Neihu Plant & 900 & 397 & 51.92 & 62 & 15.65 & January 1991 \\
\hline 2 & Taipei City Mucha Plant & 1500 & 613 & 48.07 & 81 & 13.27 & March 1995 \\
\hline 3 & Taipei City Peitou Plant & 1800 & 923 & 60.33 & 136 & 14.75 & May 1999 \\
\hline 4 & Kaohsiung City Central Plant & 900 & 674 & 88.07 & 100 & 14.84 & September 1999 \\
\hline 5 & Kaohsiung City South Plant & 1800 & 1071 & 69.99 & 251 & 23.43 & January 2000 \\
\hline 6 & Hsinchu City & 900 & 741 & 96.88 & 128 & 17.33 & February 2001 \\
\hline 7 & Taichung City & 900 & 625 & 81.69 & 104 & 16.57 & May 1997 \\
\hline 8 & Chiayi City & 300 & 232 & 90.83 & 35 & 14.98 & July 2001 \\
\hline 9 & Tain City & 900 & 607 & 79.28 & 109 & 17.97 & August 1999 \\
\hline 10 & Taipei County Hsintien Plant & 900 & 688 & 90.00 & 120 & 17.47 & November 1995 \\
\hline 11 & Taipei County Shulin Plant & 1350 & 962 & 83.88 & 161 & 16.77 & October 1995 \\
\hline 12 & Taipei County Bali plant & 1350 & 1250 & 108.96 & 229 & 18.34 & July 2001 \\
\hline 13 & Taichung County Houli Plant & 900 & 782 & 102.16 & 161 & 20.61 & August 2000 \\
\hline 14 & Changhua County Hsichou Plant & 900 & 761 & 99.49 & 153 & 20.09 & January 2001 \\
\hline 15 & Chiayi County Lutsao Plant & 900 & 832 & 108.71 & 167 & 20.12 & December 2001 \\
\hline 16 & Kaohsiung County Renwu Plant & 1350 & 926 & 80.71 & 213 & 22.98 & November 2000 \\
\hline 17 & Kaohsiung County Kangshan Plant & 1350 & 1005 & 87.62 & 234 & 23.25 & July 2001 \\
\hline 18 & Pingtung County Kandin Plant & 900 & 703 & 91.93 & 168 & 23.90 & December 2000 \\
\hline 19 & Taoyuan County Taunan Plant & 1350 & 1196 & 104.23 & 268 & 22.40 & October 2001 \\
\hline \multirow[t]{2}{*}{ Total } & (tons/day) & 21,150 & 14,988 & 85.51 & 2,881 & 18.67 & - \\
\hline & (tons/year) & $7,719,750$ & $5,470,736$ & - & $1,051,604$ & - & - \\
\hline
\end{tabular}

Note. No. $1-18$ are public infrastructure projects; No. 19 is BOT project. 
Table 2

Comparison of metal contents of MSWIs ash

\begin{tabular}{|c|c|c|c|c|c|}
\hline Metals & Bottom ash (mg/kg) & Bottom ash (mg/kg) & Fly ash $(\mathrm{mg} / \mathrm{kg})$ & Combined ash (mg/kg) & Bottom ash $(\mathrm{mg} / \mathrm{kg})$ \\
\hline $\mathrm{Ag}$ & - & $2-38$ & ND-700 & $1.8-99$ & $8.5-10.7$ \\
\hline $\mathrm{Al}$ & - & $5400-73,000$ & $5300-176,000$ & $10,000-130,000$ & $38,559-39,784$ \\
\hline As & $1-200$ & $1.3-45$ & $15-750$ & $15-87$ & $209-227$ \\
\hline $\mathrm{Ba}$ & $400-2500$ & $47-2000$ & $88-9000$ & $160-1000$ & $1104-1166$ \\
\hline $\mathrm{Ca}$ & - & $3900-120,000$ & $3960-270,000$ & $22,000-250,000$ & $>220,000$ \\
\hline $\mathrm{Cd}$ & $1-70$ & $0.3-61$ & $5-2210$ & $7-200$ & $6.8-7.8$ \\
\hline Co & $20-50$ & $22-706$ & $2.3-1670$ & - & $49.6-53.1$ \\
\hline $\mathrm{Cr}$ & $20-3000$ & $13-1440$ & $21-1900$ & $30-670$ & $323-439$ \\
\hline $\mathrm{Cu}$ & $300-8000$ & $80-10,700$ & $187-2380$ & $300-9300$ & $4139-4474$ \\
\hline $\mathrm{Fe}$ & - & $1000-133,500$ & $900-87,000$ & $3200-72,000$ & $49,320-51,448$ \\
\hline $\mathrm{Hg}$ & - & $0.003-2$ & $0.9-73$ & $<0.13-160$ & - \\
\hline $\mathrm{K}$ & - & $750-16,000$ & $11,000-65,800$ & $2300-14,400$ & $11,190-11,556$ \\
\hline $\mathrm{Mg}$ & - & $400-26,000$ & $2150-21,000$ & $1400-22,000$ & $7959-8079$ \\
\hline $\mathrm{Mn}$ & - & $50-3100$ & $171-8500$ & $250-1350$ & $869-894$ \\
\hline $\mathrm{Na}$ & - & $1800-42,000$ & $9780-49,500$ & $5900-11,000$ & $33,635-36,020$ \\
\hline $\mathrm{Ni}$ & $100-600$ & $9-430$ & 10-1970 & $20-340$ & $216-242$ \\
\hline $\mathrm{Pb}$ & $100-14,000$ & $98-6500$ & $200-2600$ & $370-22,400$ & $2471-2807$ \\
\hline $\mathrm{Se}$ & $<10$ & ND-3.4 & $0.48-16$ & $<1.2-12$ & $230-265$ \\
\hline $\mathrm{Si}$ & - & $1300-310,000$ & $1783-266,000$ & $150,000-630,000$ & $175,554-176,110$ \\
\hline $\mathrm{Zn}$ & $1000-7000$ & $200-12,400$ & $2800-152,000$ & $960-15,800$ & $4261-4535$ \\
\hline References & IAWG, 1997 & NCHRP, 2000 & NCHRP, 2000 & NCHRP, 2000 & TEPA, 2004 \\
\hline
\end{tabular}

landfill for non-combustible MSW and non-hazardous industrial waste with leachate collection and treatment, and (3) security landfill for hazardous waste with leachate collection, monitoring and treatment. Current measures require that MSWI fly ash be subjected to an intermediate treatment process to meet the criteria specified by TEPA prior to subsequent landfill disposal. These intermediate treatments include the following (TEPA, 2002c):

1. Solidification.

2. Stabilization.

3. Melting and/or

4. Other methods approved by TEPA.

In practice, the fly ash generated in most MSWIs is currently subjected to stabilization or solidification treatment for passing the TCLP test, before it is disposed of at a sanitary landfill.

Using stabilization or solidification gives a sufficient reduction of the potential of heavy metal pollution as well as lowering the operating cost for other non-hazardous pollutants.

In field monitoring of MSWIs located in northern Taiwan, we found that the compacted strength of solidified fly ash does not fit the bill, at $10 \mathrm{~kg} / \mathrm{cm}^{2}$, and the release of contaminants from solidified fly ash will be increased. These options are generally unacceptable as long-term measures from public concerns.

Research on the bottom ash utilization and technology is currently under way in Taiwan. The pilot research (TEPA, 2000) results obtained in year 2000 favors the use of melting for disposal of MSWI fly ash. Laboratory study (TEPA, 2000) results show that the compressive strength of the melted by-product from fly ash is higher than
$500 \mathrm{~kg} / \mathrm{cm}^{2}$ and is high enough for the by-product to be used as road base material or aggregate substitute. Unfortunately, the study has not provided in-depth analyses on economic feasibility. Additionally, some aspects of the key technology has not been grasped by domestic industries in Taiwan and there are still problems to be resolved before implementing this method, e.g., high operating and maintenance costs and several scale-up problems.

\section{Utilization scenario for bottom ash}

The ash utilization potential depends on the yield of incinerated ash $(\Phi)$, which is calculated as the mass ratio between generated ash and treated MSW. The total treated MSW in 2003 was 5.47 million tons and the ash generated was 1.05 million tons; hence, the average $\Phi$ is $18.67 \%$ and $\Phi$ varies between $13.27 \%$ and $23.90 \%$ for the 19 MSWIs operated during 2003.

Treatment and disposal of incinerator ash has been tracked and audited under regulatory enforcement. In the past years, there were no adequate reuse and recycle methods for useful application of the ash. The problem worsened as a result of limited space for landfill sites, difficulties in acquiring appropriate space for new landfill sites as well as by the residents' NIMBY attitude. Implementation of more stringent environmental laws will set a higher standard for the disposal of incinerator ash and make the cost very high. If, however, through adequate intermediate treatments that change the characteristics the ash is made suitable for reuse as secondary building material, the recycle and reuse of incinerator ash will not only greatly lower the disposal costs but also provide valuable materials to Taiwan that is known to be poor in natural resources. Several utilization alternatives have been 
considered, and TEPA has funded a three-year research and development project from 1998 to 2000 (TEPA, 1998, 1999, 2000). Based on the findings of this project, TEPA promulgated the Technical Directives of Utilization of Bottom Ash (Fig. 1) in 2001 in which the following five possible reuses of incinerator ash are listed (TEPA, 2001):

1. Aggregate substitute material in cement without binder, (i.e., controlled low strength material, CLSM).

2. Asphalt concrete substitute.

3. Brick product substitute.

4. Road base material.

5. Daily cover substitute material at landfill site.

Table 3 summarizes the regulations, including test methods, conditions of leaching, limit value of leaching and ash handling management strategy in Taiwan (TEPA, 2002a) and several other countries (Gerven et al., 2005; IAWG, 1997; Sakai et al., 1996). In the TEPA jurisdiction, utilization of bottom ash has been constrained by negative public opinion, lack of practical experience and standardized design criteria for engineering applications, and especially uncertainty on long-term reliability.

Three extraction tests were evaluated, namely, toxicity characteristic leaching procedures (TCLP), extraction procedure (EP), and American Society for Testing and Materials (ASTM) D3987-85 methods, for their ability to extract metals in MSWI bottom ash and chemical sludge, in terms of the precision of analytical results (Chang et al., 2001). Results show that for bottom ash, the concentration of metal leached was almost the same between the lysimetry leaching and the TCLP tests. The results of the TCLP tests for bottom ash, which has a low metal content and alkalinity, can be used to estimate the metal concentration leached by typical acid rain in Taiwan; whereas the ASTM extraction test may be a better indicator of the lysimetry test. As for metal leachability in various wastes by different extraction tests, the metal concentration followed the order: TCLP $\approx \mathrm{EP}>\mathrm{ASTM}$.

In the USA, batch leaching tests include extraction procedure toxicity (EP-Tox; US EPA Method 1310, 2001), toxicity characteristic leaching procedure (TCLP; US EPA Method 1311, 2001), synthetic precipitation leaching procedure (SPLP; US EPA Method 1312, 2001), waste extraction test (WET; California Code of Regulations, 1985), American Society for testing and materials extraction test (ASTM D3987-85, 2001), and multiple extraction procedure (MEP; US EPA Method 1320). The batch tests typically involve mixing size-reduced waste with extraction solution and then agitating the mixture. These tests generally are performed for a short period of time (typically for hours or days) and therefore are often called short-term tests. The main differences between these tests are leaching solution, $L / S$ ratio, and number and duration of extraction.

The TCLP is a batch test method with an arbitrary $L / S$ ratio, 20, which may not represent field conditions. The role of procedure is minimized as the test is performed for a standard $18 \mathrm{~h}$. The $\mathrm{pH}$ of leaching fluid does not necessarily represent the $\mathrm{pH}$ of the leaching environment. The $\mathrm{pH}$ of the leachate is highly dependent on the buffering capacity of the test materials, which may lead to an inaccurate determination of material behavior in the environment. The continued leaching of chemicals into the environment is also not addressed with the TCLP test. The application of a dilution factor to the TCLP test

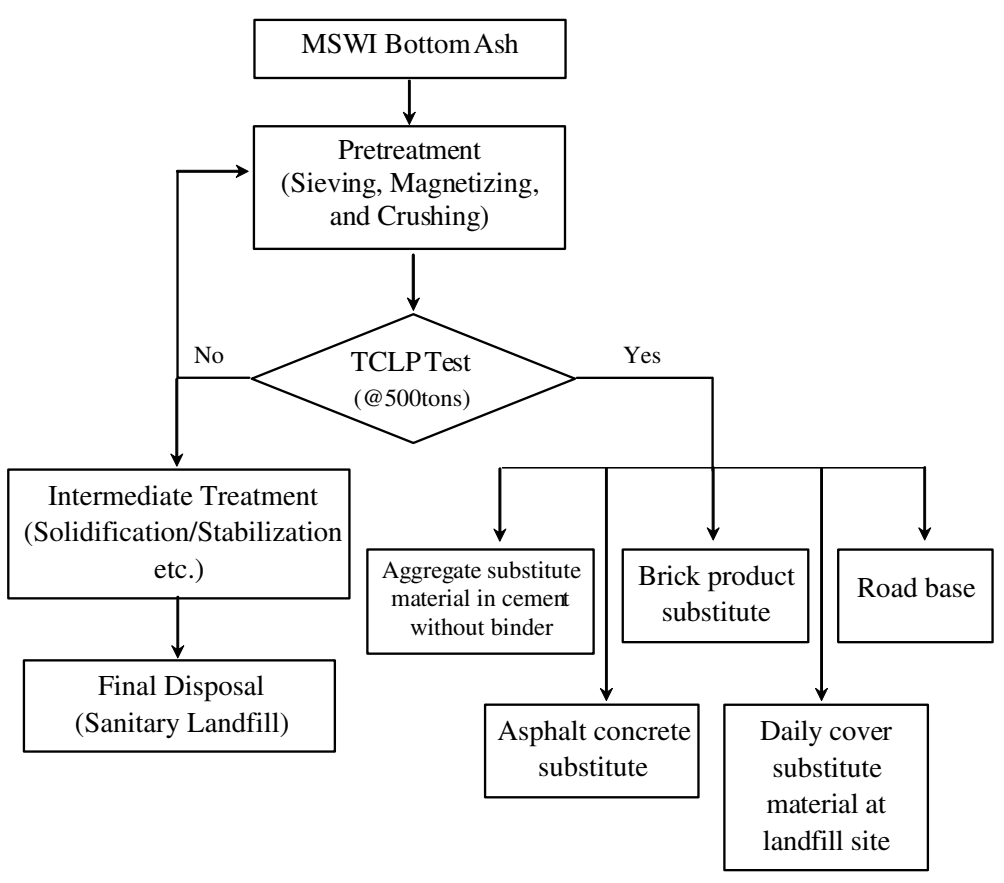

Fig. 1. Systematic process of MSWI bottom ash utilization in Taiwan. 
Table 3

MSWI ash regulations and management in Taiwan and developed countries

\begin{tabular}{|c|c|c|c|c|c|c|c|c|}
\hline Item & Taiwan & Netherlands & Denmark & Germany & France & USA & USA & Japan \\
\hline Leaching test type & $\begin{array}{l}\text { Batch (NIEA } \\
\text { R201.12C) }\end{array}$ & $\begin{array}{l}\text { Column } \\
\text { (NEN7343) }\end{array}$ & Batch (EN12457-3) & $\begin{array}{l}\text { Batch (DIN } 38414 \\
\text { S4) }\end{array}$ & Batch (NFX31-210) & $\begin{array}{l}\text { Batch (TCLP) } \\
\text { (EPA Method } \\
1311)\end{array}$ & $\begin{array}{l}\text { Batch (SPLP) (EPA } \\
\text { Method 1312) }\end{array}$ & Batch (JLT- 13) \\
\hline Steps & 1 & 7 & 1 & 3 & 3 & 1 & 1 & 1 \\
\hline L/S per step & 20 & up to 10 & 2 & 10 & 30 & 20 & 20 & 10 \\
\hline Solid & $100 \mathrm{~g}(<9.5 \mathrm{~mm})$ & $500 \mathrm{~g}(<4 \mathrm{~mm})$ & $175(<4 \mathrm{~mm})$ & $20 \mathrm{~g}(<4 \mathrm{~mm})$ & $20 \mathrm{~g}(<4 \mathrm{~mm})$ & $100 \mathrm{~g}(<9.5 \mathrm{~mm})$ & $100 \mathrm{~g}(<9.5 \mathrm{~mm})$ & $10 \mathrm{~g}(0.5-5 \mathrm{~mm})$ \\
\hline Leachant & Acetic acid (2 pHs) & Initial pH 4 & Demin. water & Distilled water & Distilled water & Acetic acid (2 pHs.) & Acetic acid (2 pHs) & Distilled water \\
\hline Duration & $18 \pm 2 \mathrm{~h}$ & 21 days ( 7 fraction) & $6 \mathrm{~h}$ & $24 \mathrm{~h} / \mathrm{step}$ & $16 \mathrm{~h} / \mathrm{step}$ & $18 \pm 2 \mathrm{~h}$ & $18 \pm 2 \mathrm{~h}$ & 6 hour \\
\hline Filtration & $0.6 \sim 0.8 \mu \mathrm{m}$ & $0.45 \mu \mathrm{m}$ & $0.45 \mu \mathrm{m}$ & $0.45 \mu \mathrm{m}$ & $0.45 \mu \mathrm{m}$ & $0.45 \mu \mathrm{m}$ & $0.45 \mu \mathrm{m}$ & $1.0 \mu \mathrm{m}$ \\
\hline Regulation limits & & $\mathrm{BMD}$, isolated & & LAGA & $\mathrm{V} \quad \mathrm{M}$ & & & \\
\hline $\mathrm{Pb}(\mathrm{mg} / \mathrm{L})$ & 5.0 & 8.7 (bottom ash) & 0.1 & 0.5 (bottom ash) & $10 \quad 50$ & 5.0 & 5.0 & 0.3 \\
\hline $\mathrm{Cd}(\mathrm{mg} / \mathrm{L})$ & 1.0 & 0.066 (bottom ash) & 0.04 & 0.05 (bottom ash) & 12 & 1.0 & 1.0 & 0.3 \\
\hline \multirow[t]{4}{*}{$\begin{array}{l}\text { Ash Handling } \\
\text { Management } \\
\text { Strategy }\end{array}$} & $\begin{array}{l}\text { - Utilization limit } \\
\text { of bottom } \\
\text { ash, i.e. substitute } \\
\text { material of } \\
\text { cement, asphalt } \\
\text { or daily cover. }\end{array}$ & $\begin{array}{l}\text { - Used in } \\
\text { embankment and } \\
\text { in road base with } \\
\text { isolated. }\end{array}$ & $\begin{array}{l}\text { - Road base, floors, } \\
\text { pipe trench. }\end{array}$ & $\begin{array}{l}\text { - Utilization limit } \\
\text { of bottom ash }\end{array}$ & $\begin{array}{l}\text { - V: Utilization in } \\
\text { road and other } \\
\text { constructions } \\
\text { without taking } \\
\text { isolation measure }\end{array}$ & $\begin{array}{l}\text { - Bottom ash use } \\
\text { under } \\
\text { consideration in } \\
\text { road construction } \\
\text { applications }\end{array}$ & $\begin{array}{l}\text { - Used to evaluate } \\
\text { the potential for } \\
\text { leaching metals } \\
\text { into ground and } \\
\text { surface waters }\end{array}$ & $\begin{array}{l}\text { - Controlled } \\
\text { landfills }\end{array}$ \\
\hline & $\begin{array}{l}\text { - Demonstrated } \\
\text { facilities to be } \\
\text { constructed. } \\
\text { - TCLP test per } \\
500 \text { tons treated } \\
\text { product. }\end{array}$ & - More than $90 \%$ & $\begin{array}{l}\text { - Utilization } \\
\text { criteria }\end{array}$ & $\begin{array}{l}\text { - Used bottom } \\
\text { ash, scrap metal }\end{array}$ & $\begin{array}{l}\text { - M: Need } \\
\text { treatment before } \\
\text { recycling. }\end{array}$ & $\begin{array}{l}\text { - Normally } \\
\text { "monofill" }\end{array}$ & & \\
\hline & $\begin{array}{l}\text { - Fly ash } \\
\text { considered } \\
\text { hazardous must } \\
\text { be treated with } \\
\text { specified } \\
\text { methods. }\end{array}$ & $\begin{array}{l}\text { - ESP fly ash: } \\
\text { hazardous } \\
\text { landfills. Or use } \\
\text { as asphalt filler }\end{array}$ & $\begin{array}{l}\text { - National disposal } \\
\text { facilities to be } \\
\text { constructed }\end{array}$ & $\begin{array}{l}\text { - Hazardous waste } \\
\text { landfills } \\
\text { - Salt mines }\end{array}$ & $\begin{array}{l}\text { - S: Landfilled in a } \\
\text { Cat-II landfill } \\
\text { with prior } \\
\text { stabilization if } \\
\text { need. }\end{array}$ & $\begin{array}{l}\text { - Double lined } \\
\text { landfills with } \\
\text { caps, leachate } \\
\text { collection }\end{array}$ & & $\begin{array}{l}\text { - Considered } \\
\text { hazardous, must } \\
\text { be treated with a } \\
\text { specified method }\end{array}$ \\
\hline & $\begin{array}{l}\text { - Presently, } \\
\text { solidified or } \\
\text { stabilized and } \\
\text { sent to lined } \\
\text { landfills }\end{array}$ & $\begin{array}{l}\text { - APC residues: } \\
\text { big bags at a } \\
\text { controlled landfill }\end{array}$ & $\begin{array}{l}\text { - Presently sent to } \\
\text { lined landfill } \\
\text { facilities or stored }\end{array}$ & & $\begin{array}{l}\text { - Fly ash and APC } \\
\text { residues have to } \\
\text { be landfilled in a } \\
\text { Cat-I landfill. }\end{array}$ & & & \\
\hline
\end{tabular}


results when conducting a risk-based management evaluation is also not defined. Therefore, TCLP's broad application and use as the only acceptable test for most risk-based waste management decisions has been questioned (Kosson et al., 1996, 2002; USEPA, 1991, 1999). The TCLP was developed specifically to address the co-disposal of hazardous waste in an organic waste landfill. As a result, the TCLP may not allow for extrapolation of long-term environmental effects, nor does it address different leaching mechanisms. Leaching behavior of metals from wastes is more complex than can be determined by a single batch test.

Since 2002, TEPA promulgated the Resource Recycling and Reuse Act (TEPA, 2002f) to promote waste reduction, resource recovery, and green purchasing based on sustainable development. Although TEPA promotes the recycling and reuse of incinerator ash, standards for engineering practice have not been specified. Additionally, the ash needs to be upgraded by sieving and removal of metal fractions before it can be used in construction. There are also limitations on the quantity and area for ash application for protecting the environment and human health. For example, the area of ash application should not exceed $2000 \mathrm{~m}^{2}$ for a single construction and the TCLP test should be implemented for each 500 tons of bottom ash. Thus, private companies and public construction departments have not adopted the incinerator ash as an alternative construction material especially for large-scale construction projects.

In Taiwan one bottom ash treatment plant, a drying sieving system with a capacity of 944 tons/day, has been in operation for three MSWIs of Taipei County since
2003. The drying process of bottom ash includes magnetic separation of ferrous, non-ferrous separation, sieving and crushing of particles $>25 \mathrm{~mm}$, with additives such as phosphorus acid, is not standard procedure. In Taipei County, three MSWIs incinerated in 2003 about 1,059,000 tons of solid wastes. This led to 161,930 tons of bottom ash and to 24,556 tons of solidified fly ash (including APC residue and boiler ash) (Table 4). Fig. 2 illustrates the fraction of MSW treated and recovery in 2003.

The National Cooperation Highway Research Program (NCHRP) published the Waste and Recycled Materials Information Database, a performance approach for application to Waste and Recycled Materials (WRMs) for use in transportation-related engineering (NCHRP, 2000). The database was sponsored by the American Association of State Highway and Transportation Officials (AASHTO), in cooperation with the Federal Highway Administration (FHWA) and was conducted under the auspices of NCHRP, which is administrated by the Transportation Research Board (TRB) of the National Research Council (NRC). The WRM Information Database contains information on 21 WRMs including municipal waste combustor ash, coal bottom ash, coal fly ash, etc. for use in transportation related engineering applications.

Developed as a modification of the USEPA's extraction procedure test, the TCLP was intended to simulate the conditions that might occur in a landfill where decomposing garbage is present. The TCLP test involves extracting contaminants from a $100 \mathrm{~g}$ size-reduced sample of waste material with an appropriate extraction fluid. A specific $L / S$ ratio, 20, is employed, and the mixture is rotated for $18 \pm 2 \mathrm{~h}$ at $30 \mathrm{rpm}$. The extraction fluid of TCLP depends

Table 4

Treatment profile of MSWI ash in Taiwan (2003)

\begin{tabular}{llclllllrr}
\hline Unit & $\begin{array}{l}\text { Ash from } \\
\text { incinerator }\end{array}$ & Ash to landfill & $\begin{array}{l}\text { Solidified fly } \\
\text { ash to landfill }\end{array}$ & $\begin{array}{l}\text { Secondary building } \\
\text { material }\end{array}$ & Iron & Copper & Aluminum & Stainless steel & Non-combustible \\
\hline $\begin{array}{l}\text { Ton per year } \\
\%\end{array}$ & $1,051,604$ & 865,108 & 24,566 & 145,446 & 14,315 & 162 & 453 & 130 & 1425 \\
& 100 & 82.27 & 2.34 & 13.83 & 1.36 & 0.02 & 0.04 & 0.01 & 0.14 \\
\hline
\end{tabular}

Note. Ash to landfill: excluding three plants from Taipei County.

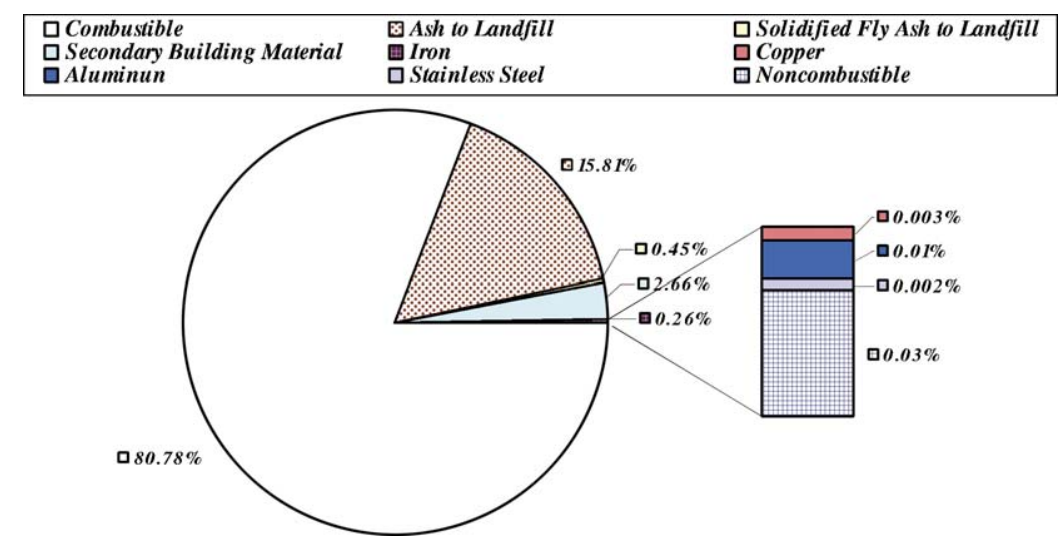

Fig. 2. Fractions of MSW treatment and recovery. 
on the alkalinity of the waste material. Very alkaline waste materials are leached with a fixed amount of glacial acetic acid without buffering the system $(\mathrm{pH} 2.88 \pm 0.05)$, while other waste materials are leached with glacial acetic acid buffered at $\mathrm{pH} 4.93 \pm 0.05$ with $1-\mathrm{N}$ sodium hydroxide. After rotation, the final $\mathrm{pH}$ is measured, and the mixture is filtered using a glass fiber filter. The filtrate is collected in an appropriate container, and a preservative may be added if needed. The filtrate is analyzed for a number of constituents. If these constituents exceed the concentrations describing in 40 CFR 261, the waste is hazardous for the TC (unless otherwise excluded).

The ASTM test (ASTM D 3987-85) is a deionized extraction test to simulate a condition in which waste material is a dominant factor in determining the $\mathrm{pH}$ of the extract. The test uses a $70 \mathrm{~g}$ sample of size-reduced waste material (less than $10 \mathrm{~mm}$ ) with reagent water using $L / S$ ratio of 20 for $18 \pm 0.25 \mathrm{~h}$ at $30 \mathrm{rpm}$. This test has been recommended to determine leachability of inorganic constituents only and is not applicable to organic substances.

Many waste leaching tests have been commonly used in various countries for regulatory purposes. More thorough descriptions and procedures of these leaching tests can be found in the literature (van der Sloot et al., 1997). However, in this guide only a few of these leaching tests are introduced for the purpose of comparison with the leaching tests that have been frequently used in the USA.

The DIN38414-S4 batch test, which is a standardized German leaching procedure for water, wastewater, sediment, and sludge testing, has been widely used for regulatory purposes. This test uses a $100 \mathrm{~g}$ size-reduced sample with unbuffered demineralized water using an $L / S$ ratio of 10 ; the test is run for $24 \mathrm{~h}$ while agitating.

In France, the NFX 31-210 batch extraction test for granular solid mineral waste has been employed for regulatory purposes. The NFX procedure is similar to the German batch test, DIN 38414-S4, but uses a smaller particle size (less than $4 \mathrm{~mm}$ ). In the NFX test, the material is leached for $16 \mathrm{~h}$, but the elute is repeated twice reusing the residues on the $0.45 \mu \mathrm{m}$ filter membrane for $L / S$ is 30 (Gerven et al., 2005).

In the Netherlands, the availability test (NEN 7341) is the Dutch standard leaching test for assessing maximum leachability of waste for regulatory purposes. The procedure consists of reducing the particle size of waste $(<125 \mathrm{~mm})$, extracting with leaching solution of $\mathrm{pH} 7 \mathrm{fol}-$ lowed by $\mathrm{pH} 4$ using nitric acid or sodium hydroxide, and agitating for $3 \mathrm{~h}$. The $\mathrm{pH}$ conditions are consistently maintained throughout the test. The extract in each step is combined for chemical analysis.

The NEN 7349 test is another Dutch regulatory batch leaching test for granular waste. This test is a serial batch test consisting of five successive extractions of waste material with demineralized water. The test is first run at $\mathrm{pH} 4$ using nitric acid at an $L / S$ ratio of 20 for $23 \mathrm{~h}$, followed by four successive extractions with fresh leaching solution.

\section{Decision-making process}

There are also other factors affecting decisions of bottom ash utilization, such as resource conservation, construction project, population density, land availability, energy requirements, environmental regulations, and public acceptance. The construction industry has not accepted TEPA's guidelines on bottom ash utilization, which obstructs the application of bottom ash on a practical scale. Thus, TEPA will continue research on recycle and reuse of incinerator ash. This paper will target the concerns not currently addressed by TEPA's research and propose recommendations for improvement as shown in Fig. 3. TEPA will investigate the demonstration projects to measure the potential of utilization of the bottom ash. The process of decision-making is shown in Fig. 3. The process requires that government agencies including TEPA, Ministry of Transportation and Communication (MOTC, for road construction engineering specifications), Industrial Development Bureau of Ministry of Economic Affairs

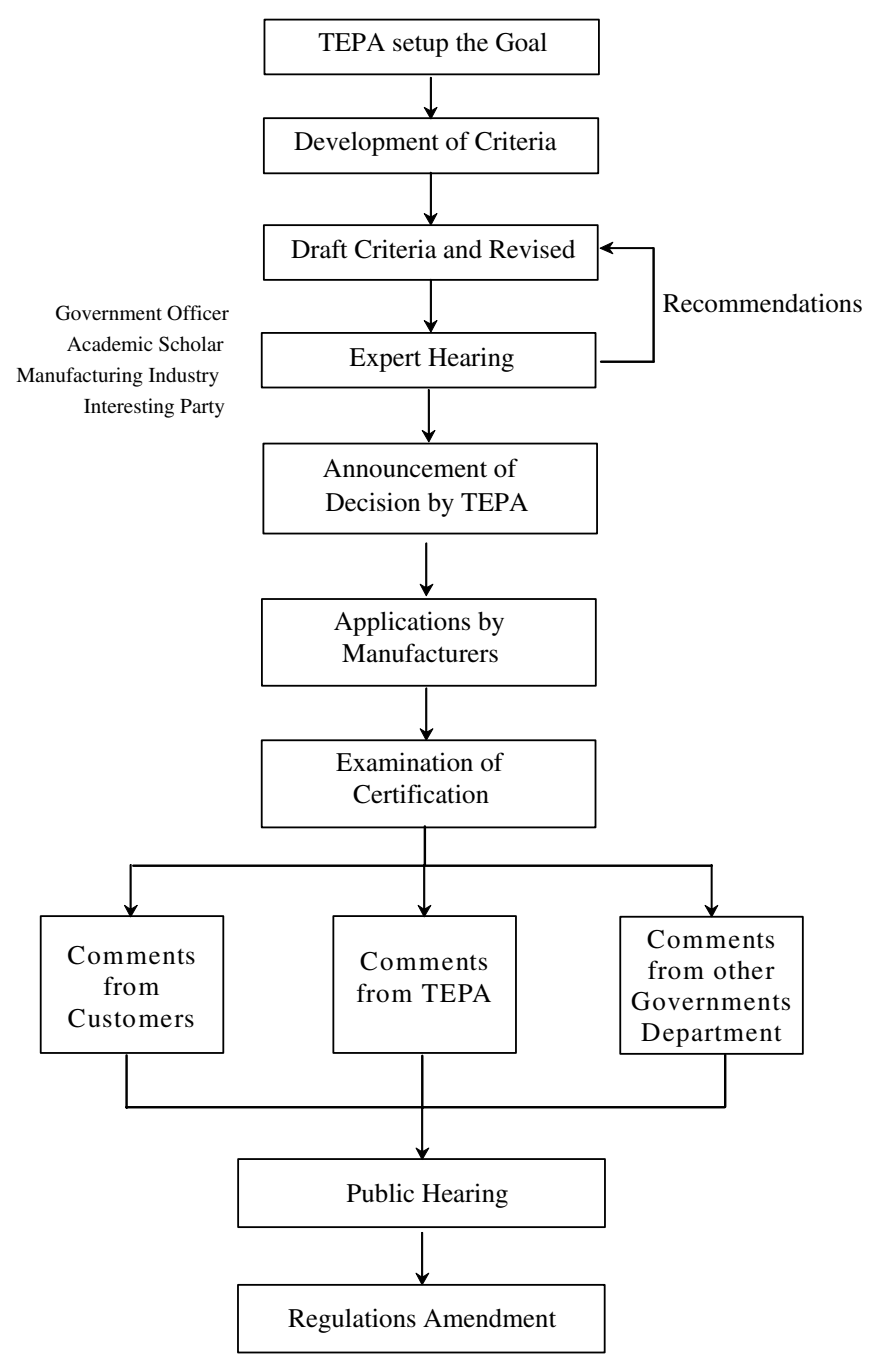

Fig. 3. Decision-making process of MSWI ash utilization. 
(MOEA/IDB, for manufacturing industry), Construction and Planning Administration of Ministry of Interior (MOI/CPA, for concrete product guidelines or specifications), senior experts, academic scholars, manufacturing industry and the public participate in public hearings to discuss and make recommendations on the proposed criteria. In order to promote the utilization of bottom ash, TEPA initiated a demonstration project on bottom ash utilization starting on September 2002, to set up two demonstration facilities for utilizing bottom ash (TEPA, 2002e). Based on the results obtained by field studies, TEPA will inspect the ash for the following parameters:

\section{Physical properties}

(1) particle size distribution,

(2) moisture content,

(3) bulk density,

(4) compressive strength,

(5) permeability,

(6) porosity.

2. Chemical characteristics

(1) chemical composition,

(2) loss on ignition,

(3) heavy metal leachability,

(4) organic constituent,

(5) chloride content.

\section{Conclusion}

With respect to the management of MSW, the use of incineration with waste-to-energy conversion will be the standard treatment method in the coming decades in Taiwan. The amount of ash generated is now 1.05 million tons per year, including $90 \%$ bottom ash and $10 \%$ fly ash. The average yield is 0.192 tons of ash per ton of waste. To address public concerns, TEPA has adopted stringent regulations to reduce risk in bottom ash utilization and minimize the emission of pollutants in the flue gas from MSWI. In addition to providing technical guidelines for bottom ash utilization, TEPA has initiated a demonstration project for obtaining field data to affirm the policy of bottom ash utilization and to revise the technical criteria, if needed. In this way, risk in the whole utilization process will be minimized, and the benefit and cost-effectiveness of the selected strategies on bottom ash utilization will be maximized. The authors provided the decision-making procedure for the concept of bottom ash utilization compatible with the environment. There are several limits to the procedure:

1. Decision making tools are not validated for waste treatment scenarios, e.g., impact on aquatic environment.

2. This procedure is applicable for short or medium term assessments. Investigations on the long term impact and prediction need be considered.
The diversity in the development of MSWI ash handling technology reflects differences in the level of industrialization, scarcity of land for ash landfill, consumption habits and wealth of the country.

We recommend TEPA to refer to the aforementioned TCLP issues. Also, if ash is being treated, the treated product should be tested and monitored to determine the likelihood of leaching.

\section{Acknowledgments}

The authors thank the Associate Editor and the referees for their valuable comments.

\section{References}

Chang, E.E., Chiang, P.C., Lu, P.H., Ko, Y.W., 2001. Comparisons of metal leachability for various wastes by extraction and leaching methods. Chemosphere 45, 91-99.

Gerven, T.V., Geysen, D., Stoffels, L., Jaspers, M., Wauters, G., Vandecasteele, C., 2005. Management of incinerator residues in Flanders (Belgium) and in neighbouring countries. A comparison. Waste Management 25, 75-87.

IAWG, 1997. Municipal Solid Waste Incinerator Residues. Studies in Environmental Sciences, vol. 67. Elsevier, Amsterdam, The Netherlands.

Kosson, D.S., van der Sloot, H.A., Eighmy, T.T., 1996. An approach for estimating of contaminant release during utilization and disposal of municipal waste combustion residues. Journal of Hazardous Material 47, 43-75.

Kosson, D.S., van der Sloot, H.A., Sanchez, F., Garrabrants, A.C., 2002. An integrated framework for evaluating leaching in waste management and utilization of secondary materials. Environmental Engineering and Science 19, 159-204.

NCHRP, 2000. Waste and Recycled Materials Use in the Transportation Industry-NCHRP 4-21, information Database User's Manual.

Sakai, S., Sawell, S.E., Chandler, A.J., Eighmy, T.T., Kosson, D.S., Vehlow, J., van der Sloot, H.A., Hartlen, A.J., Hjelmar, O., 1996. World trend in municipal solid waste management. Waste Management 16, 341-350.

van der Sloot, H.A., Heasman, L., Quevauviller, P., 1997. Harmonization of Leaching/Extraction tests. Studies in Environmental Sciences, vol. 70. Elsevier, Amsterdam, The Netherlands.

TEPA, 1998. Development of Reuse Technologies of Municipal Solid Waste Incinerator Ashes and Their Regulations (I), Taipei, Taiwan.

TEPA, 1999. Development of Reuse Technologies of Municipal Solid Waste Incinerator Ashes and Their Regulations (II), Taipei, Taiwan.

TEPA, 2000. Development of Reuse Technologies of Municipal Solid Waste Incinerator Ashes and Their Regulations (III), Taipei, Taiwan.

TEPA, 2001. Technical Directives of Utilization of Municipal Solid Waste Incinerator Bottom Ash, Taipei, Taiwan.

TEPA, 2002a. Standards for Defining Hazardous Waste, Taipei, Taiwan.

TEPA, 2002b. NIEA R201.12C, Toxicity Characteristic Leaching Procedure (TCLP) for Industrial Waste, Taipei, Taiwan.

TEPA, 2002c. The Project on Planning, Design, and Construction of Facility for Municipal Solid Waste Incinerator Bottom Ash Utilization, Taipei, Taiwan.

TEPA, 2002d. The Project on Revised of Measures for Recycling, Removal and Disposal of General Wastes, Taipei, Taiwan.

TEPA, 2002e. Measures for Recycling, Removal and Disposal of General Wastes, Taipei, Taiwan. 
TEPA, 2002f. Resource Recycling and Reuse Act, Taipei, Taiwan.

TEPA, 2004a. Yearbook of Environmental Protection Statistics, Taipei, Taiwan.

TEPA, 2004b. The Research on the Utilization of MSWI residues (II). EPA-93-U1H1-02-101, Taipei, Taiwan.
USEPA, 1991. Leachability Phenomena. EPA-SAB-EEC-92-003. USEPA Science Advisory Board, Washington, DC.

USEPA, 1999. Waste Leachability: The Need for Review of Current Agency Procedures. EPA-SAB-EEC-COM-99-002. USEPA Science Advisory Board, Washington, DC. 